\title{
MIXED-SPECIES ASSOCIATION AMONG MALAYSIAN PRIMATES DURING THE COVID-19 OUTBREAK IN GENTING HIGHLANDS, PENINSULAR MALAYSIA
}

\author{
BADRUL MUNIR MD-ZAIN*1, ABD RAHMAN MOHD-RIDWAN ${ }^{1,2}$, HANI NABILIA MUHD- \\ SAHIMI $^{3}$, MUHAMMAD ABU BAKAR ABDUL-LATIFF ${ }^{4}$ AND EDDIE CHAN $^{5}$ \\ ${ }^{1}$ Department of Biological Sciences and Biotechnology, Faculty of Science and Technology, Universiti Kebangsaan \\ Malaysia, 43600, Bangi, Selangor, Malaysia. ${ }^{2}$ Centre for Pre-University Studies, Universiti Malaysia Sarawak, 94300, Kota \\ Samarahan, Sarawak, Malaysia. ${ }^{3}$ Department of Wildlife and National Parks (DWNP), KM 10 Jalan Cheras, 56100 Kuala \\ Lumpur, Malaysia. ${ }^{4}$ Centre of Research for Sustainable Uses of Natural Resources, Faculty of Applied Sciences and \\ Technology, Universiti Tun Hussein Onn Malaysia (Pagoh Campus), 84000, Muar, Johor, Malaysia, ${ }^{5}$ Treks Events Sdn Bhd, \\ Lot AW/G5.00, GF, Awana Hotel Genting Highlands Resort.
}

*Corresponding author: abgbadd@ukm.edu.my

Submitted final draft: 31 August $2020 \quad$ Accepted: 5 September 2020

http://doi.org/10.46754/jssm.2021.01.001

\begin{abstract}
This is the first report to elucidate primate mixed-species association during Covid-19 outbreak in Malaysia. The observations were carried out at Genting Highlands between 14-24th April 2020 using ad libitum sampling. Five Genting Highlands primate species were observed at approximately 66 observation hours which include Symphalangus syndactylus (siamang), Trachypithecus obscurus obscurus (dusky langur), Presbytis siamensis siamensis (Malayan pale-thighed surili), Macaca nemestrina (southern pig-tailed macaque), and Macaca fascicularis (long-tailed macaque). Primates in Genting Highlands were seen interacting among themselves during the third phase of the MCO. Siamangs, dusky langurs, and long-tailed macaques were observed sharing space and interacting in an old section of Genting View Resorts that is currently under renovation. Malayan palethighed langurs were also observed approaching this area. During the third phase of the MCO, siamangs, dusky langurs, long-tailed macaques, and pig-tailed macaques consumed fruits of the fig tree (Ficus benjamina), which last for only one week. Strict controls on public movement are believed to have created environmental conditions that enabled Genting Highlands primates to move and interact freely among themselves.
\end{abstract}

Keywords: Movement Control Order, COVID-19, Malaysian primates, mixed species association.

\section{Introduction}

After initially appearing in Wuhan City, Hubei Province, China, SARS-CoV-2 unfortunately made its way to Malaysia. COVID-19 was confirmed in Malaysia on January 25, 2020, having been brought into the country by a Chinese tourist from Wuhan, who traveled from Singapore to Johor Bahru on January 22, 2020 (CPRC, 2020). In the first wave of infections, only 22 positive COVID-19 cases were recorded and this was followed by 11 days of zero reported cases. However, an explosive second wave of infections began on February 27, 2020, and an astonishing 651 cases had been reported by March 17, 2020 (Figure 1).

The Government of Malaysia immediately announced and implemented the Movement
Control Order (MCO) under the Prevention and Control of Infectious Diseases Act 1988 andthe Police Act 1967. The MCO came into force on March 18, 2020 and severely restricted the movement of the public and prevented gatherings nationwide. It closed all kindergartens, public and private schools, public and private higher learning institutions, and government and private premises (except those providing essential services), limited overseas travel, limited foreign visitors and tourists to Malaysia and many other restrictions (Prime Minister's Office of Malaysia, 2020). Despite enforcement of the first phase of this historical and unprecedented order (March 18, 2020-March 31, 2020) throughout the country, the number of new COVID-19 cases continued to increase, only plateauing occasionally (Figure 1). This caused the government to subsequently 


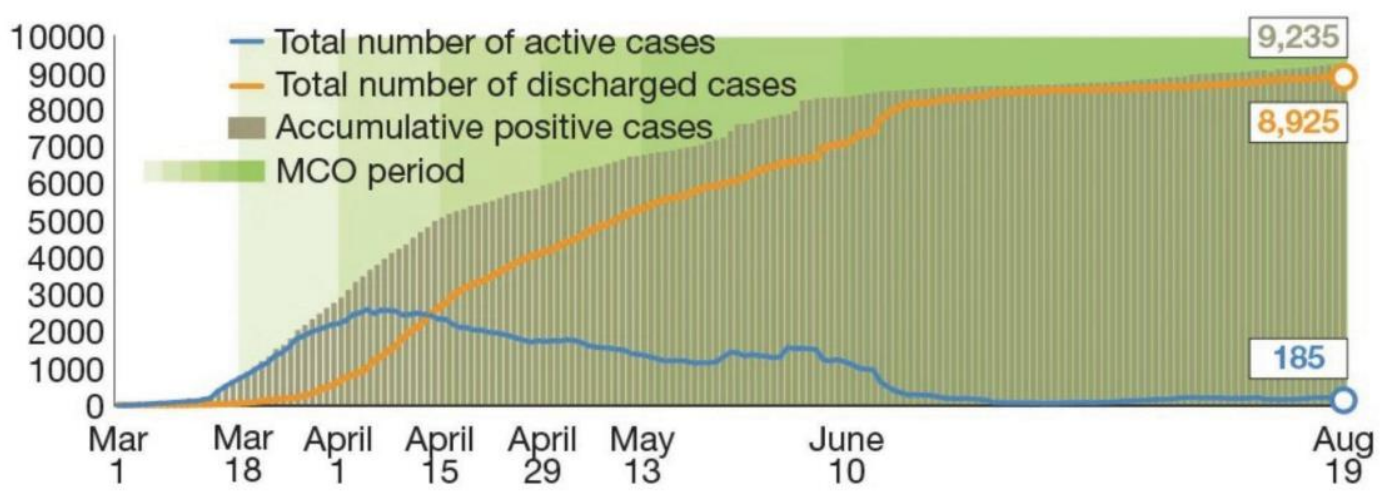

Figure 1: COVID-19 cases in Malaysia (The Edge Markets; data from the Ministry of Health, updated Aug 19, 2020)

extend the MCO into a second phase (April 1, 2020-April 14, 2020), third phase (April 15, 2020-April 28, 2020), fourth phase (April 29, 2020-May 3, 2020), conditional MCO phase (May 4, 2020-June 9, 2020) and recovery MCO phase (June 10, 2020- August 31, 2020). As of August 19 2020, a total of 9,235 positive cases, 8925 cured and 125 deaths have been recorded in Malaysia.

\section{Effects of COVID-19 lockdowns worldwide on wildlife}

The COVID-19 pandemic and consequent lockdowns have had a major impact on wildlife worldwide. Decreases in human pressure and movements due to lockdown measures have reduced stress on wildlife. Wild animals have been roaming freely in the absence of humans. For example, the sika deer that normally live in Japan's Nara Park were seen roaming in adjacent cities (The New York Times, 2020). In Wales, mountain Kashmiri goats wandered onto the streets of Llandudno town (The Guardian, 2020). In Spain, boars were spotted in the city center of Barcelona (Strait Times, 2020). Inthe Chilean capital of Santiago, a puma was spotted in the deserted streets (CNBC, 2020). Meanwhile, in Malaysia, a Malayan tapir was seen wandering the streets of Kuantan, Pahang (AsiaOne, 2020). In the same city, a wild boar was spotted roaming around a neighborhood
(AsiaOne, 2020). In Terengganu, a group of wild elephants was seen near a gas station and a single wild elephant was also sighted outside a hospital in Kluang, Johor (AsiaOne, 2020).

The COVID-19 pandemic has also affected non-human primates worldwide in many ways. Urban non-human primates, such as macaques, have been exhibiting altered behaviour during COVID-19 lockdowns. For example, in India, Rhesus macaques in the temple town of Ayodhya have been reported attacking visitors due to starvation (National Herald, 2020). It was also reported that Rhesus macaques in India assaulted a laboratory assistant and escaped with a batch of coronavirus blood tests (Sky News, 2020). In another case, a macaque was seen holding onto the string and reel of an airborne kite (New York Post, 2020). In terms of other species, a gray langur was seen running along a deserted road in Ahmedabad, India (Forbes, 2020). In Thailand, hundreds of long-tailed macaques overran the capital of Lop Buri in search of food after a decline in tourism during the pandemic (Bangkok Post, 2020). Meanwhile, in Malaysia, long-tailed macaques were seen swimming in a condominium pool in Tanjung Bungah, Penang (The Star, 2020). Herein, here, we reported a letter to editor a brief survey of primate mixedspecies association in Genting Highlands during the MCO period. 


\section{Materials and Methods}

\section{Study site and field sampling}

Genting Highlands $\left(3^{\circ} 25^{\prime} 25^{\prime \prime} \mathrm{N} \quad 101^{\circ} 47^{\prime} 36^{\prime \prime} \mathrm{E}\right)$ is located in Bentong District, Pahang, about $50 \mathrm{~km}$ from the capital city of Malaysia, Kuala Lumpur (Ng et al., 2012). Genting Highlands is synonymous with entertainment, hospitality, and tourism as well as nature. The observation area of the present study was at Genting View Resort, Genting Highlands, now known as GVR. The old section of the resort was under renovation, although work stopped when the MCO was instituted on March 18, 2020. The primate observations in the present study were carried out between 14th-24th April of 2020(11 days) using ad libitum sampling with 66 hours of observation (Altmann, 1974) from an apartment block occupied by one of the authors, which is fronted by an untouched patch of forest that is part of the forest lands owned by Genting Malaysia. The data before MCO was also obtained based on selected observationsbetween early 2018 and early March of 2020. The behaviours such as intra- and inter- species interaction and feeding were observed. Plants eaten by primates were identified based on photographs and reconfirmed by plant expert (Dr Shamsul Khamis) from Universiti Kebangsaan Malaysia (UKM).

\section{Result and Discussion}

Primate communities of Genting Highlands

Of the 66 hours of observation, five speciesof primate have been recorded in Genting Highland: Symphalangus syndactylus siamang, Trachypithecus obscurus obscurus dusky langur, Presbytis siamensis siamensis Malayan pale-thighed langur, Macaca nemestrina pigtailed macaque, and Macaca fascicularis longtailed macaque (Table 1, Figure 2). There is one territorial siamang family (Ramses group) that inhabits this forest section and this family has been seen on the perimeter ofthe forest on many occasions but does not stray far into the resort compound. The dusky langur is a more frequent visitor than the Malayan pale-thighed langur. Both pig-tailed macaques and long-tailed macaques were observed daily inthe forest and resort compound during the studyperiod.

Apart from primates, many bird species were sighted, including eagles, hornbills, barbets, bulbuls, forest pigeons, malkohas, kingfishers, and woodpeckers in addition to more common birds such as starlings, magpie-robins, swallows, and sparrows. Wild boar, squirrels, and shrews were also occasionally sighted. When the MCO was enforced, human movements immediately ceased on the main roads of Genting Highlands, at Genting Highlands Resorts and the Awana Hotel, in the shopping areas in Goh Tong Jaya and Genting Permai, and within the GVR

Table 1: List of Malaysian primates found in Genting Highlands with IUCN, International Union for Conservation of Nature red list category

\begin{tabular}{|c|c|c|c|c|}
\hline No. & Species & Common name(s) & Local name(s) & IUCN category \\
\hline 1 & $\begin{array}{l}\text { Presbytis siamensis } \\
\text { siamensis }\end{array}$ & $\begin{array}{l}\text { Malayan pale-thighed } \\
\text { langur, white-thighed surili }\end{array}$ & $\begin{array}{l}\text { Lutong Ceneka } \\
\text { Lutong Kakoh }\end{array}$ & Near threatened \\
\hline 2 & $\begin{array}{l}\text { Trachypithecus } \\
\text { obscurus obscurus }\end{array}$ & $\begin{array}{l}\text { Dusky langur, dusky leaf } \\
\text { monkey, spectacled langur }\end{array}$ & $\begin{array}{l}\text { Lutong Celak } \\
\text { Lutong Chengkong }\end{array}$ & Endangered \\
\hline 3 & Macaca fascicularis & Long-tailed macaque & Kera & Vulnerable \\
\hline 4 & Macaca nemestrina & Southern pig-tailed macaque & Beruk & Endangered \\
\hline 5 & $\begin{array}{l}\text { Symphalangus } \\
\text { syndactylus }\end{array}$ & Siamang & Siamang & Endangered \\
\hline
\end{tabular}




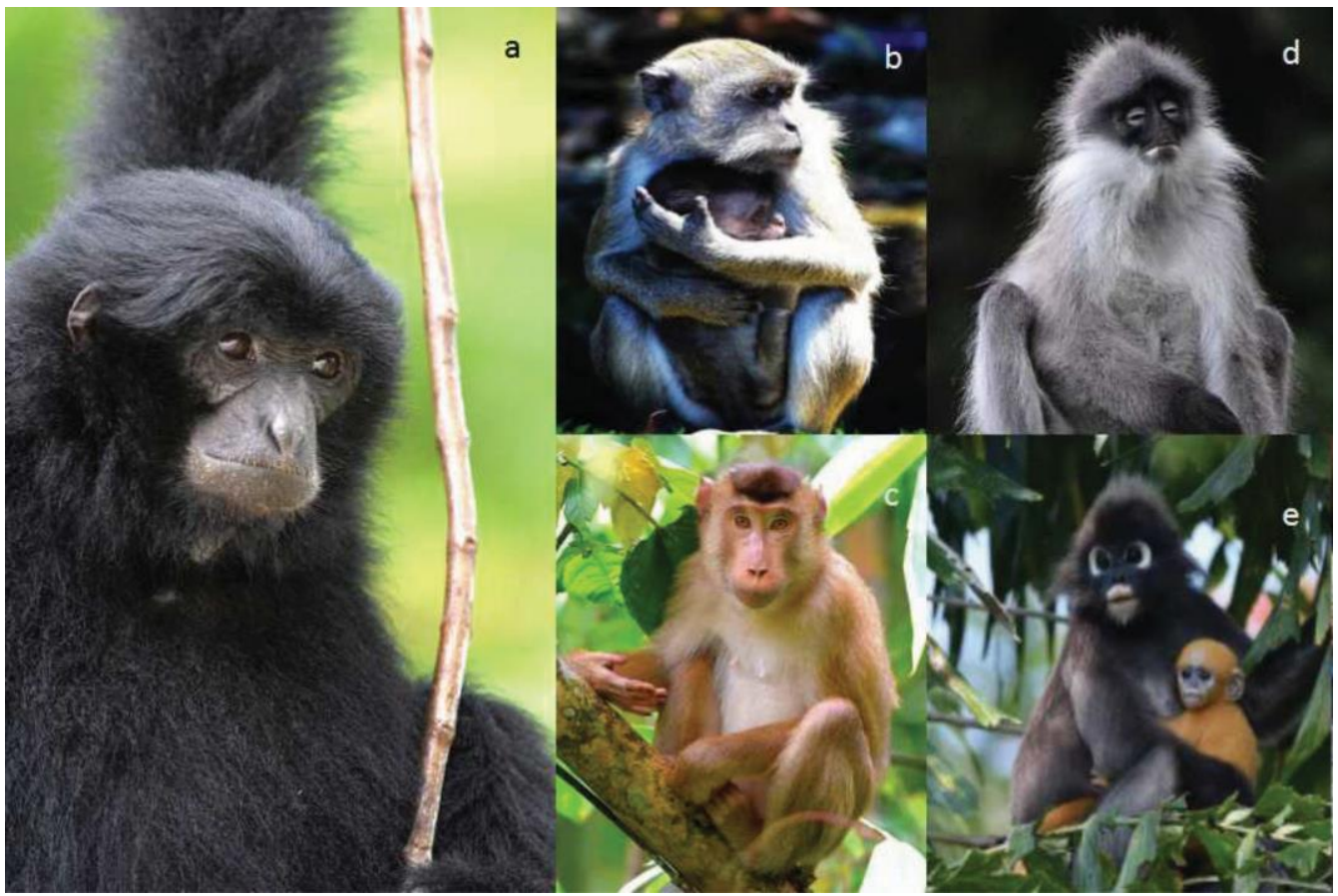

Figure 2: Primates of Genting Highlands: a) Symphalangus syndactylus, b) Macaca fascicularis, c) Macaca nemestrina, d) Presbytis siamensis siamensis, e) Trachypithecus obscurus obscurus)

compound. Security check points were strictly manned and only essential traffic was allowed through, especially to and from Genting Highlands.

The prevailing weather from the beginning of the first phase of the MCO (March 18, 2020) to the middle of May 2020 was very fair with many consecutive clear, sunny days and blue skies. This offered many picturesque sunrises and sunsets and a number of rainbows with some rain during the evenings and nights, though generally not every night (Figure 3 ). There were also many clear nights and the full moon and stars were clearly visible with the naked eye during this period (Figure 3). The temperatures during the day were generally a little warmer than average and the relative humidity was lower than average during this period. There was also generally less mist and heavy fog during this period than usual, although there were some misty mornings after the rain in the early hours. The nights were cool but not cold (below $20^{\circ} \mathrm{C}$ ) due to the warmer and drier conditions during the days.

\section{Mixed-species association among primates in Genting Highlands}

Before the $M C O$

Before the MCO, primates in Genting Highlands appeared active and undisturbed despite the presence of humans, development, and busy roads. Siamang family groups could be seen enjoying their morning routines, calling, roaming freely, and feeding calmly. As siamang family groups consumed the fruits, shoots, and leaves of trees in Genting Highlands (such as Ficus sp. and Caryota sp.), it can be concluded this area provides the habitat required for siamang to survive. As development occurs almostevery year in Genting Highlands, siamang are considered to be very adaptive to the compact forest environment, which is fragmented by roads and buildings. The development does not only occur within the resort compound, but also surrounding the resorts. Most of the siamang family groups in Genting Highlands are increasing year by year in terms of individual 


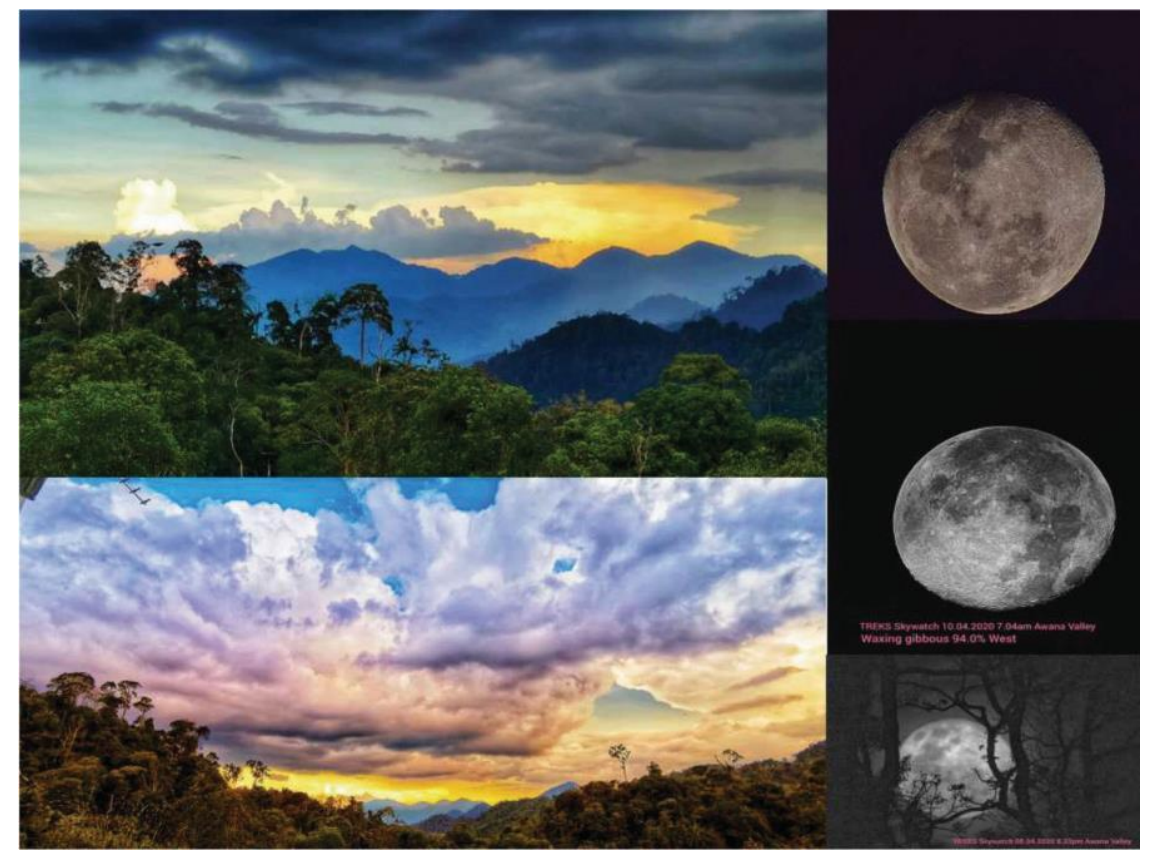

Figure 3: Environmental conditions during the Movement Control Order, as seen from the observer's apartment balcony

numbers, which bodes well for the survival of the species. There are about 12 established familygroups that had been recognised living nearby the forest edges. The numbers in each familygroups were between two to five individuals. However, the exact number of family-groups including the unseen is expected to be more than that. In several cases, siamang family groups have been observed crossing roads and cable car lines. Other species of Cercopithecinae and Colobinae can be seen along the main roads in Genting Highlands and in nearby residential areas.

\section{During the $M C O$}

In the present study, a dusky langur was observed interacting socially with a long-tailed macaque (Figure 4). This interaction was observed on April 17, 2020, during the third phase of the MCO, and involved an individual dusky langur and an individual long-tailed macaque playing at GVR. This kind of close interaction between these species was rarely seen before the MCO. Encounters between two groups of Cercopithecidae observedbefore the MCO always led to aggressiveness, possibly due to competition for space and food resources (Valenca-Silva et al., 2014). Mixed- species association among the Cercopithecidae, especially involving dusky langurs and longtailed macaques, has been reported in several locations in Peninsular Malaysia as their distribution ranges are sympatric (Md-Zain \& Ch'ng, 2011; Md-Zain, 2019; Taufet-Rosdi, 2020). Ruslin et al. (2019) reported that there are 59 plant species that are consumed by both dusky langurs and long-tailed macaques, and the dietary overlap is the highest for fruits. Thus, as space and food were commonly shared between Cercopithecinae and Colobinae, itwas not surprising to observe social interaction between these subfamilies in the present study. Nonetheless, the interaction was very interesting and occurred exclusively during the third phase of the MCO. Such interaction had also been observed in Bukit Malawati, Kuala Selangor where silvered-leaf monkeys shared their habitat with long-tailed macaques (Hambali et al., 2016). 
Other interactions were observed during the third phase of the MCO between Hylobatidae and Cercopithecidae. Individual siamangswere seen to approach dusky langurs and long- tailed macaques on separate occasions at GVR (Figure 5). The interactions were by no means aggressive; the siamangs were trying to get closer to the other species.

Feeding behaviour was among the daily activities observed. Most Genting Highlands primates fed on fig trees (Ficus benjamina). These trees are an important food resource for nearly $80 \%$ of Genting Highlands primates. MacKinnon and MacKinnon (1980) studied the effects of diet and seasonality on feeding behaviour in coexisting populations of $M$. fascicularis and T. o. obscurus in secondary dipterocarp forest and found limited dietary overlap between the species.

In the present study, $F$. benjamina fruits were consumed in one week especially for two consecutive days (April 14, 2020 and April 15, 2020) at the end of the second phase and the beginning of the third phase of the MCO (Figure $6,7)$. The fig trees began fruiting early in the first phase of the MCO. Group members ate together. On April 14-15, 2020, a group of pigtailed macaques (20 individuals), dusky langurs (10 individuals), and long-tailed macaques (12 individuals) gathered together to eat the fruits of a fig tree. However, these Cercopithecidae groups left the tree as siamangs of the Ramses group (four individuals) approached to feed. Ramses group is one territorial siamang family groups that inhabits this forest section. This family has been seen on the perimeter of the forest on many occasions however, they do not stray far into the resort compound. Additionally, a group of Malayan pale-thighed langurs made their approach, although they consumed only leaves. In addition to feeding activities, social activities such as grooming and playing were observed during the MCO (Figure 8). Grooming and playing are group bonding activities that are more common in langurs and macaques (Md-Zain \& Ch'ng, 2011; Ampeng \& Md-Zain, 2012).

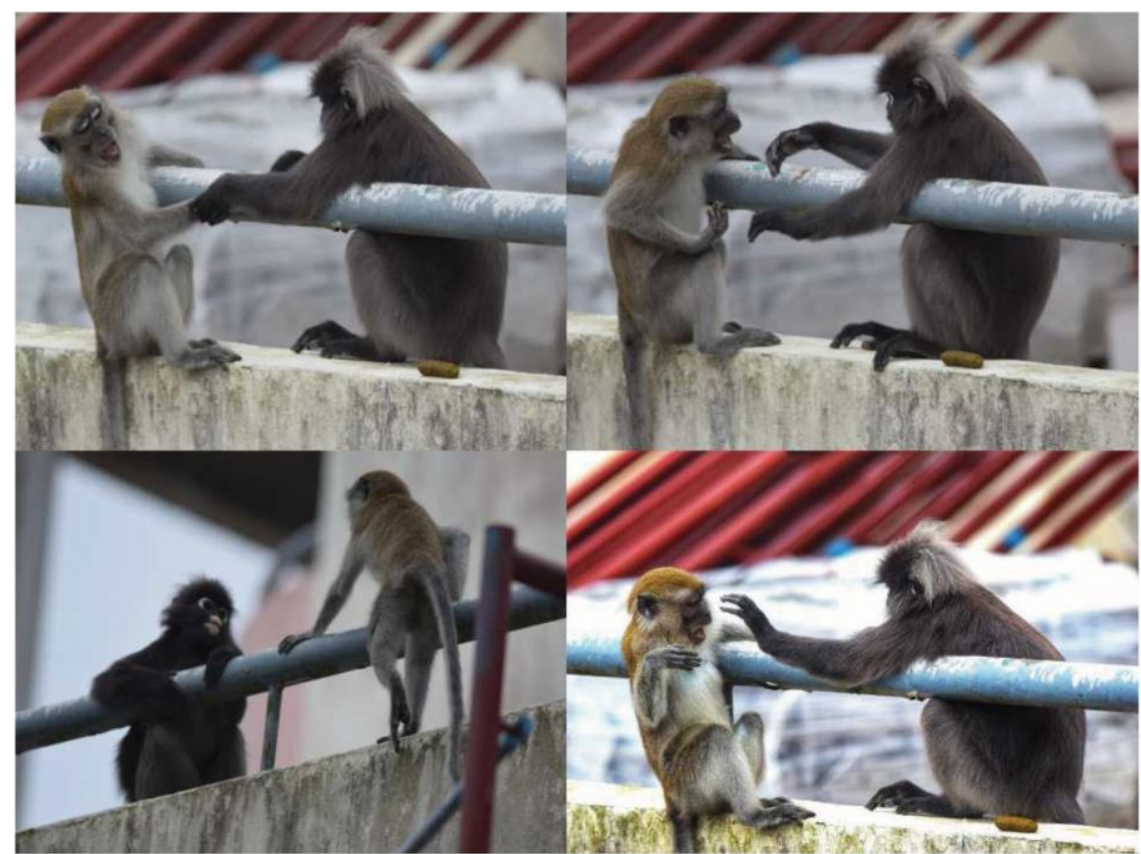

Figure 4: Mixed-species association between T. obscurus and M. fascicularis during the Movement Control Order on April 17, 2020. 


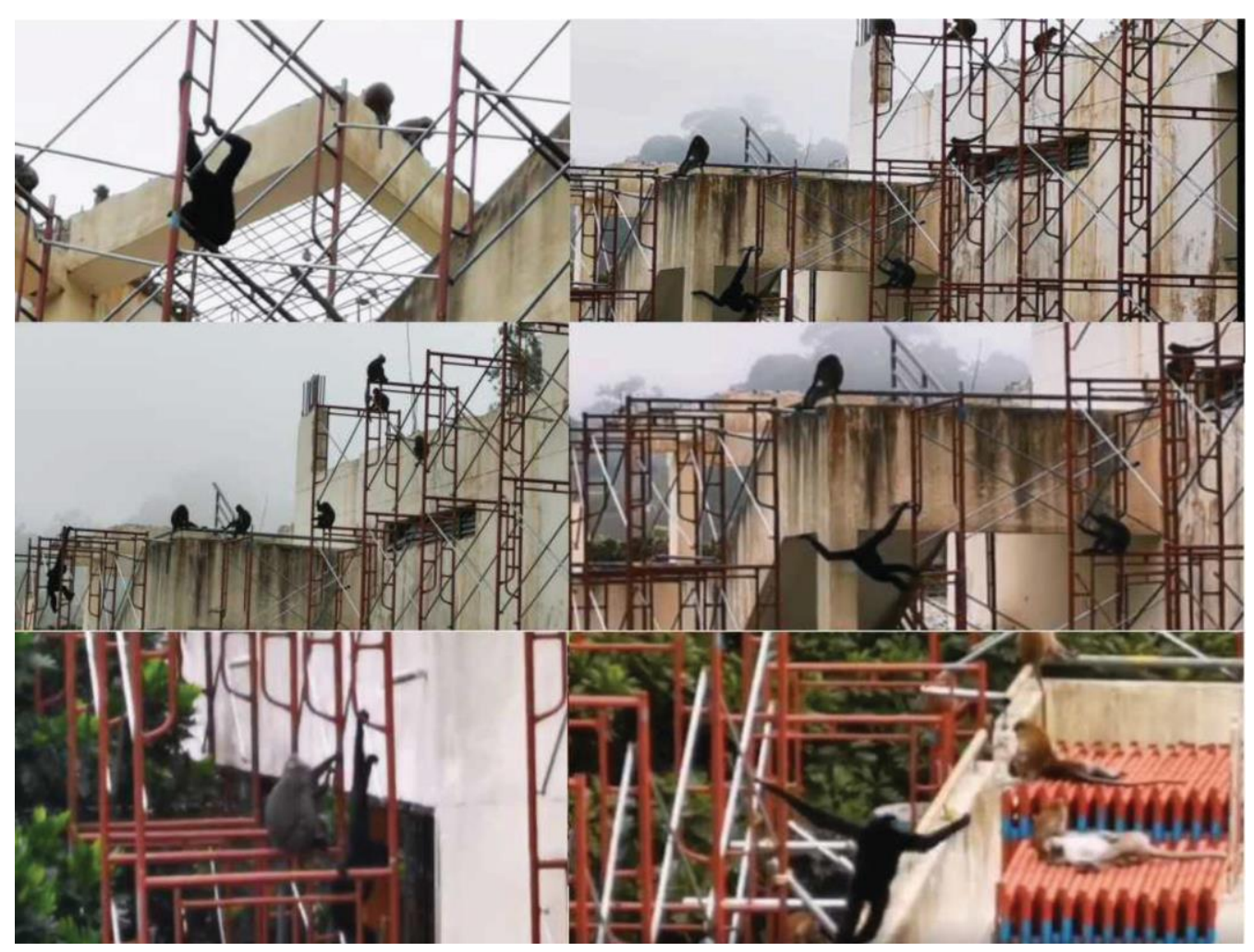

Figure 5: Interactions between S. syndactylus and T. obscurus (April 15, 2020) and between S. syndactylus and M. fascicularis (April 17, 2020)

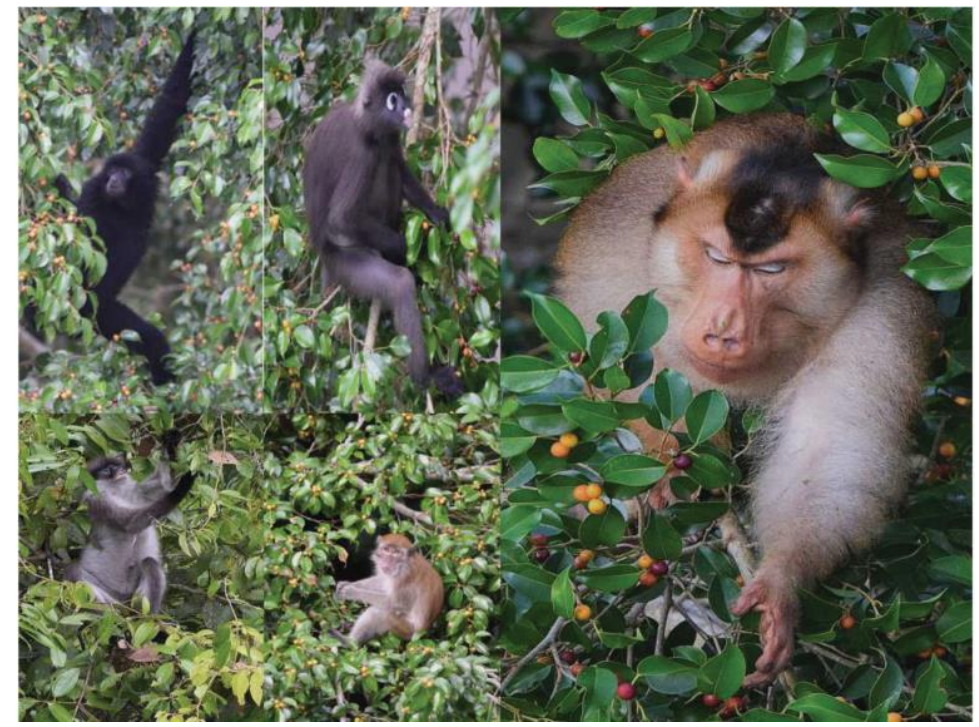

Figure 6: Genting Highlands primates; Sympalangus syndactylus, T. obscurus, M. nemestrina (from top left to right) and M. fascicularis (bottom middle) on a fruiting Ficus benjamina fig tree (April 14, 2020 and April 15, 2020) and Presbytis siamensis (bottom left) on a Cinnamomum iners tree (April 24, 2020) 


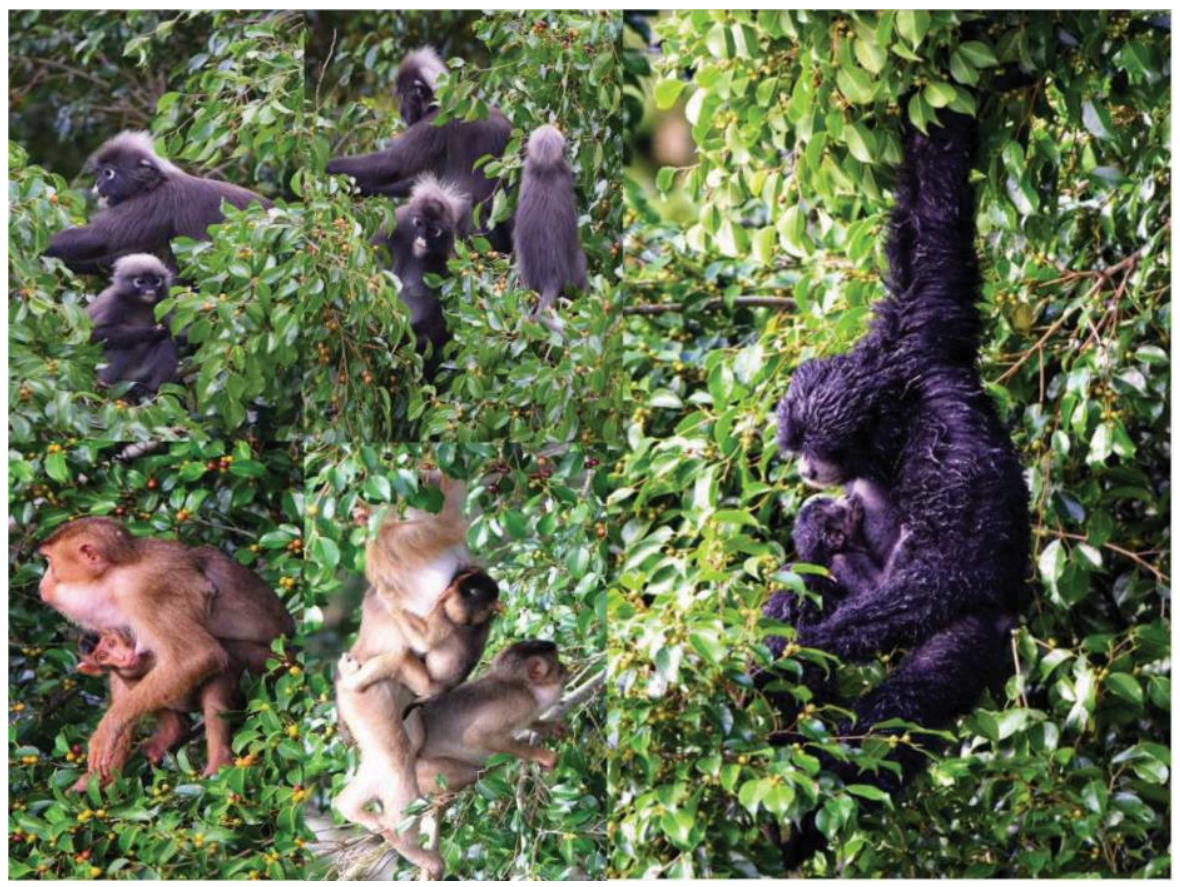

Figure 7: Genting Highlands primates; T. obscurus (from top left to top middle), S. syndactylus (right), M. nemestrina (bottom left and middle) on a fruiting fig tree (April 14, 2020 and April 15, 2020)

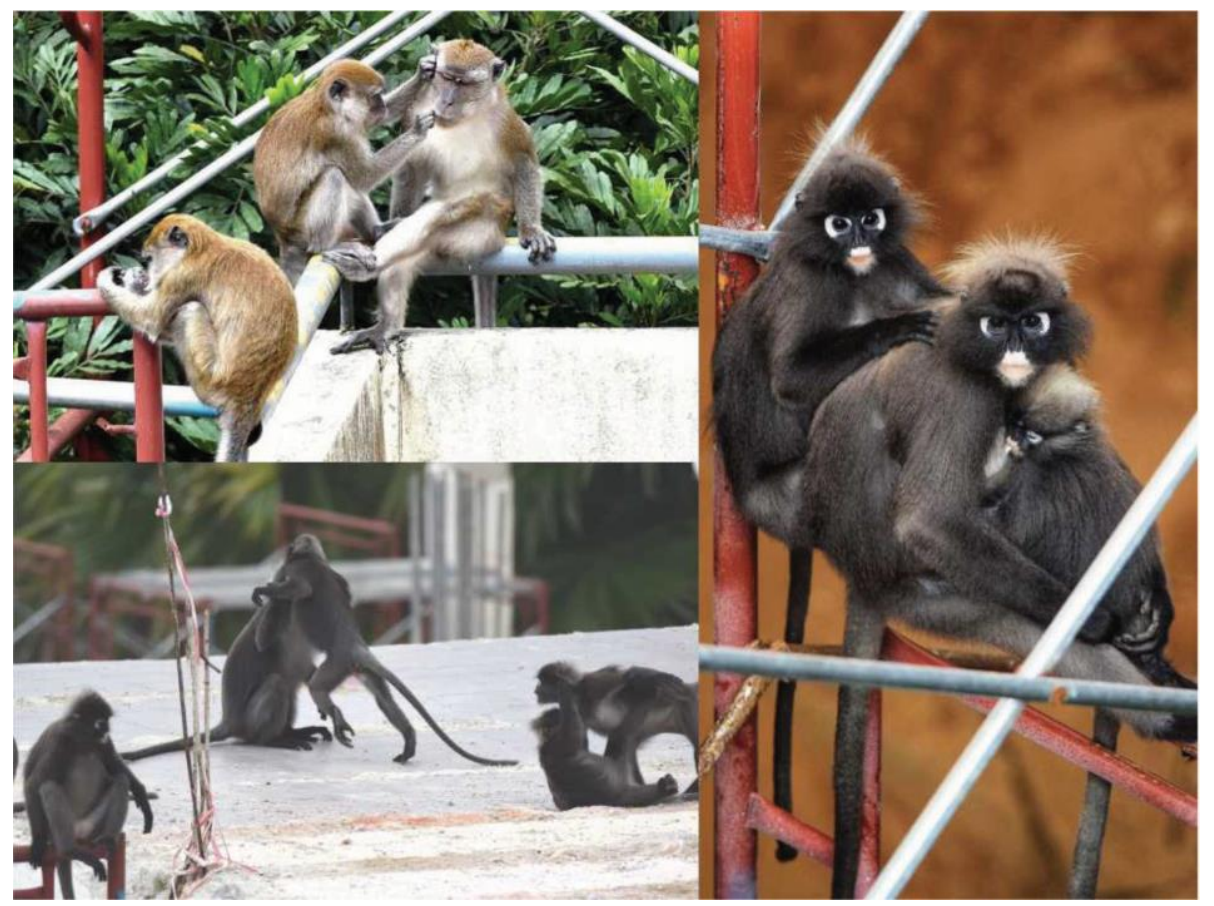

Figure 8: Grooming and playing in M. fascicularis (Top left) and T. obscurus (Top right and bottom left) (April 18, 2020) and (April 19, 2020) 


\section{Conclusions}

When primate density is high in certain areas, mixed-species association may occur. Such associations were observed among Genting Highlands primates during the COVID-19 outbreak in Malaysia. As human activities decreased during the pandemic, primates extended their ranges into a construction site. Social behaviours such as approaching, playing, and grooming among the primates were observed, especially during the third phaseof the MCO. The primates were also observed sharing food resources.

\section{Acknowledgments}

We thank Department of Wildlife and National Parks (DWNP) and Genting Malaysia forthe primate research collaborations. We would like to thank DWNP staffs (Mr. Zainal Abdullah Zawawi, Mr. Rosedan Mat Ami, Mr. Azharuddin Baharuddin, Mr. Imizam Saleh) for their accompanied trips before MCO phase. We appreciate Dr Shamsul Khamis from Universiti Kebangsaan Malaysia for his contribution on tree species identification. The authors acknowledge Faculty of Science and Technology, Universiti Kebangsaan Malaysia for providing the necessary funding and assistance. This research was supported by grant Universiti Kebangsaan Malaysia GUP-2019-037, and Universiti Tun Hussein Onn Malaysia FRGS/1/2018/WAB13/ UTHM/03/2.

\section{References}

Altmann, J. (1974). Observational study of behavior: sampling methods. Behaviour, 49(3-4), 227-266.

Ampeng, A., \& Md-Zain, B. M. (2012). Ranging patterns of critically endangered Colobine, Presbytis chrysomelas chrysomelas. The Scientific World Journal, 2012, 594382.

Asiaone. (2020). Animal crossing: Wildlife in Asia come out to play during lockdown. Retrieved from https://www.asiaone.com/ asia/animal-crossing-wildlife-asia-comeout-play-during-lockdown.

Bangkok Post. (2020). Monkey brawl in Lop Buri shocks humans. Retrieved from https://www.bangkokpost.com/thailand/ general/1876489/monkey-brawl-in-lopburi-shocks-humans.

CNBC. (2020). As coronavirus restrictions empty streets around the world, wildlife roam further into cities. Retrieved from https://www.cnbc.com/2020/04/10/ coronavirus-empty-streets-around-theworld-are-attracting-wildlife.html.

Crisis Preparedness and Response Centre (CPRC). (2020). Ministry of Health Malaysia.

Forbes. (2020). See animals around the world enjoying cities while you can't. Retrieved from https://www.forbes.com/sites/ brittanyanas/2020/04/29/see-animalsaround-the-world-enjoying-cities-whileyou-cant/\#57eb34c17beb.

Hambali, K., Md-Zain, B. M., \& Amir, A. (2016). Daily movement, sleeping sites and canopy level use of habituated silvered- leaf monkeys (Trachypithecus cristatus) in Bukit Malawati, Kuala Selangor, Malaysia. Journal of Sustainability Science and Management, 11(2), 21-30.

MacKinnon, J. R., \& MacKinnon, K. S. (1980). Niche differentiation in a primate community. In Malayan forest primates (pp. 167-190). Springer, Boston, MA.

Md-Zain, B. M., \& Ch`ng, C. E. (2011). The activity patterns of a group of Cantor' dusky 1 eaf monkeys (Trachypithecus obscurus halonifer). International Journal of Zoological Research, 7(1), 59-67.

Md-Zain, B. M. (2019). Current updates on the Malaysian primate diversity from molecular perspectives. Paper presented in the Expert Lecture Series, The Primate Business, 21 August 2019, Departmentof Wildlife and National Parks (DWNP), Kuala Lumpur. 
National Herald. (2020). Lockdown impact: Starving monkeys attacking human beings in Ayodhya. Retrieved from https://www. nationalheraldindia.com/india/lockdownimpact-starving-monkeys-attackinghuman-beings-in-ayodhya.

New York Post. (2020). Monkey appears to fly kite during coronavirus lockdown in India. Retrieved from https://nypost. com/2020/04/22/monkey-appears-to-flykite-during-coronavirus-lockdown-inindia/.

Ng, Y. J., Rusea, G., Rosmiah. N., Khor, H. E., Tan, M. C., Farah, A. N., Ahmad, A. N., \& Lee, N. S. (2012). Orchids of Cloud Forest in Genting Highlands, Pahang, Malaysia. Sains Malaysiana, 41(5), 505-526.

Prime Minister's Office of Malaysia. (2020). The Prime Minister's special message on Covid-19 on 16 March 2020. Retrieved from https://www.pmo.gov.my/2020/03/ perutusan-khas-yab-perdana-menterimengenai-covid-19-16-mac2020/.

Ruslin, F., Matsuda, I., \& Md-Zain, B. M. (2019). The feeding ecology and dietary overlap in two sympatric primate species, the longtailed macaque (Macaca fascicularis) and dusky langur (Trachypithecus obscurus obscurus), in Malaysia. Primates, 60(1), 41-50.

Sky News. (2020). Coronavirus: Monkeys 'escape with COVID-19 samples' after attacking lab assistant. Retrieved from https://news.sky.com/story/coronavirusmonkeys-escape-with-covid-19-samplesafter-attacking-lab-assistant-11996752.
Strait Times. (2020). Nature takes back world's city streets emptied by coronavirus outbreak. Retrieved from https://www. straitstimes.com/world/europe/naturetakes-back-worlds-city-streets-emptied-bycoronavirus-outbreak.

Taufet-Rosdi, N. E. A. (2020). Human-primate interactions and ecotourism: the case of Malaysian Cercopithecidae in Gunung Keriang, Kedah. BSc Thesis, Universiti Kebangsaan Malaysia, Malaysia.

The Guardian. (2020). Llandudno marauders:the herd of goats running riot through aWelsh town. Retrieved from https://www. theguardian.com/news/2020/mar/31/ llandudno-goats-herd-running-riotcoronavirus-lockdown.

The New York Times. (2020). Brawling Monkeys. Wandering Deer. Blame Coronavirus. Retrieved from https://www. nytimes.com/2020/03/16/science/hungrymonkeys-deer-coronavirus.html.

The Star. (2020). 'Monkey business' goes on in condo pool. Retrieved from https://www. thestar.com.my/news/nation/2020/03/29/ monkey-business-goes-on-in-condo-pool.

Valenca-Silva, G., Maciel, F. D. G., Zaganini, R. L., Lucindo, A. D. S., Caramaschi, S., \& Paula, H. M. G. D. (2014). Reporting social behaviours of mixed-species troops formed by Callithrix jacchus and Callithrix penicillata (Primate, Callitrichidae). Brazilian Journal of Biology, 74(3), 607611. 